\title{
PENGARUH PROBLEM BASED LEARNING BERBASIS ASESMEN KINERJA TERHADAP PENGUASAAN KONSEP FISIKA DITINJAU DARI KERJA ILMIAH
}

\author{
Conidia Ristiastuti Jehanus \\ Hena Dian Ayu \\ Chandra Sundaygara \\ Pendidikan Fisika, Fakultas Sains dan Teknologi, Universitas Kanjuruhan Malang \\ Email: ristiastutijehanus96@gmail.com
}

\begin{abstract}
Abstrak
Penelitian ini bertujuan untuk mengetahui pengaruh Problem Based Learning (PBL) berbasis asesmen kinerja terhadap penguasaan konsep fisika ditinjau dari kerja ilmiah siswa. Rancangan penilitian menggunakan posttest control group design. Teknik pengambilan sampel purposive sampling dengan instrumen penelitian adalah soal tes dan lembar observasi. Hasil anasilis menunjukkan pelaksanaan pembelajaran menggunakan PBL berbasis asesmen kinerja berbeda dengan PBL. Hal ini dibuktikan dari perhitungan uji anova dua jalur penguasaan konsep fisika menunjukkan sig $0,000<0,05$. Perhitungan uji anova dua jalur penguasaan konsep fisika berdasarkan kemampuan kerja ilmiah juga menunjukkan sig $0,019<0,05$, artinya penguasaan konsep fisika siswa yang memiliki kemampuan kerja ilmiah tinggi berbeda dengan siswa yang memiliki kemampuan kerja ilmiah rendah. Sehingga disimpulkan bahwa $P B L$ berbasis asesmen kinerja berpengaruh terhadap penguasaan konsep fisika yang ditinjau dari kerja ilmiah.
\end{abstract}

Kata Kunci: PBL, Asesmen Kinerja, Kerja Ilmiah, Konsep Fisika.

\section{PENDAHULUAN}

Salah satu mata pelajaran yang sulit adalah fisika, hal ini dikarenakan pembelajaran sering mempelajari sesuatu yang abstrak, suasana pembelajaran yang kurang menyenangkan, guru lebih dominasi dalam pembelajaran dan kemampuan kinerja siswa yang masih minim
(Ayu, H. D., Pratiwi, H. Y., Sentot, K., \& Muhardjito, 2017:335). Pembelajaran fisika seharusnya memberikan pengalaman langsung pada siswa sehingga menambah kemampuan dalam memahami, menguasai dan menerapkan konsep yang telah dipelajari (Ayu \& Jufriadi, 2017:2). Pembelajaran fisika 
hendaknya mampu melibatkan siswa dalam memperoleh pengetahuan serta menumbuhkan kemampuan bernalar untuk menguasai konsep dan memecahkan masalah yang diberikan oleh guru. Keberhasilan proses pembelajaran salah satunya ditentukan oleh interaksi antar siswa yang terlibat secara aktif dalam memecahkan masalah yang diberikan oleh guru (Ayu, H. D., Sundaygara, C., \& Pratiwi, H. Y, 2015:47). Untuk mengaktifkan siswa dalam memperoleh dan mempraktekkan pengetahuan, maka diperlukan proses pembelajaran yang membuat siswa terlibat aktif dalam proses pembelajaran sehingga mampu mencetak generasi muda yang tangguh dan berkarakter sains (Sinensis \& Firdaus, 2017:103).

Model Problem Based Learning atau yang kemudian disingkat PBL merupakan model pembelajaran yang berpusat pada siswa yang menggunakan masalah nyata sebagai landasannya untuk penyelidikan dalam meningkatkan pengetahuannya sendiri serta menumbuhkembangkan keterampilan yang lebih tinggi (Pelawi \& Sinulingga, 2016:33).
Model ini membuat siswa aktif dalam proses pembelajaran karena pada awal pembelajaran siswa akan dihadapkan pada masalah dunia nyata (real world) dan memecahkan masalah melalui kerja ilmiah (Yoesoef, 2015:97). Masalah yang disajikan dalam model PBL dapat memudahkan siswa dalam menguasai konsep-konsep yang dipelajari..

Beberapa penelitian telah menunjukkan bahwa model PBL dapat meningkatkan penguasaan konsep siswa dibandingkan dengan pembelajaran konvensional (Yoesoef, 2015:97). Pada pelaksanaan model PBL , siswa masih mengalami kesulitan dalam memecahkan masalah. Manakala siswa tidak memiliki minat atau tidak mempunyai kepercayaan bahwa masalah yang dipelajari sulit untuk dipecahkan, maka mereka merasa enggan untuk mencobanya.

Kesulitan pemecahan masalah fisika siswa dapat diatasi dengan melakukan penilaian terhadap kinerja siswa selama proses pembelajaran menggunakan model PBL. Hal ini dilakukan dengan tujuan untuk mendorong siswa agar tetap aktif 
dalam proses pembelajaran (Dewi, $\mathrm{T}$. M. A., Suwatra, W.I., \& Sumantri, M, 2016:6). Asesmen kinerja adalah sebuah prosedur yang menggunakan tugas-tugas atau latihan untuk mendapatkan informasi tentang bagaimana seorang siswa belajar dengan baik. Teknik asesmen kinerja dapat membantu dan mempermudah kegiatan pengamatan terhadap proses pembelajaran yang berlangsung (Arinata, D.C.A., Suniasih, W.N.,\& Darsana, W. I., 2017:8) Artinya, hasil-hasil kerja yang ditunjukkan dalam proses pelaksanaan pembelajaran digunakan sebagai basis untuk dilakukan suatu pemantauan/ penilaian terhadap produk dari aktivitas tersebut. Jadi, asesmen kinerja dapat mendorong siswa untuk terlibat aktif dalam pembelajaran, serta mempermudah siswa untuk memahami sebuah konsep dari abstrak ke konkret.

Aplikasi asesmen kinerja dalam pembelajaran fisika juga akan mengembangkan kemampuan kerja ilmiah siswa. Kemampuan kerja ilmiah merupakan suatu kegiatan yang melatih siswa untuk tidak hanya menerima konsep jadi, melainkan menuntut siswa untuk membuktikan cara memperoleh konsep tersebut (Hudha \& Aji, 2016:835). Kegiatan ini membantu siswa untuk dapat mengingat topik pembelajaran dalam jangka panjang dan meningkatkan penguasaan konsep siswa. Melalui asesmen kinerja siswa dibiasakan untuk menunjukkan kinerjanya dalam segala hal, lebih kususnya kegiatan memecahkan masalah, mengutarakan pendapat, berdiskusi maupun memberikan alasan dari jawaban yang diberikan.

Berdasarkan kajian teori dan hasil penelitian tentang aplikasi asesmen kinerja, ternyata dalam pembelajaran memberi pengaruh positif kepada peserta didik antara lain membantu memahami dan memecahkan masalah yang dihadapi siswa, membantu meningkatkan hasil belajar siswa mengembangkan kemampuan kerja ilmiah siswa dalam memecahkan masalah dalam konteks yang berbeda (Dewi et al., 2016:6).

\section{METODE}

Rancangan yang digunakan dalam penelitian ini adalah 


\section{C, R, Jehanus., H, D, Ayu., C, Sundaygara. - Pengaruh Problem Based ...}

rancangan posttest only control yang digunakan adalah teknik group design dengan pola faktorial

2x2. Adapun matriks rancangan analisis penelitian munurut menggunakan faktorial dua faktor dengan pola yang dapat dilihat pada tabel 1. Teknik pemilihan sampel purpuse sampling dengan instrumen penelitian adalah soal tes berbentuk uraian untuk mengukur penguasaan konsep fisika siswa dan lembar observasi untuk mengukur kemampuan kerja ilmiah siswa.

Tabel 1. Matriks Rancangan Anova Dua Jalur

\begin{tabular}{|c|c|c|c|}
\hline \multicolumn{2}{|c|}{ Variabel Bebas } & \multicolumn{2}{|c|}{ Model Pembelajaran (B) } \\
\hline \multicolumn{2}{|c|}{ Variabel Moderat } & $\begin{array}{l}\text { Model PBL Berbasis } \\
\text { Asesmen Kinerja (B1) }\end{array}$ & $\begin{array}{l}\text { Model PBL } \\
\text { (B2) }\end{array}$ \\
\hline \multirow{2}{*}{$\begin{array}{l}\text { Kerja ilmiah } \\
\text { (A) }\end{array}$} & Tinggi (A1) & B1A1 & B2A1 \\
\hline & Rendah (A2) & B1A2 & B2A2 \\
\hline
\end{tabular}

Keterangan:

B1A1 : Penguasaan konsep fisika dengan pemberian perlakuan kepada kelompok yang menggunakan model $P B L$ berbasis asesmen kinerja untuk siswa yang mempunyai kerja ilmiah tinggi.

B1A2 : Penguasaan konsep fisika dengan pemberian perlakuan kepada kelompok yang menggunakan model $P B L$ berbasis asesmen kinerja untuk siswa yang mempunyai kerja ilmiah rendah.

B2A1 : Penguasaan konsep fisika dengan pemberian perlakuan kepada kelompok yang menggunakan model $P B L$ untuk siswa yang mempunyai kerja ilmiah tinggi.

B2A2 : Penguasaan konsep fisika dengan pemberian perlakuan kepada kelompok yang menggunakan model $P B L$ untuk siswa yang mempunyai kerja ilmiah rendah.

\section{HASIL DAN PEMBAHASAN}

Secara umum tujuan penelitian ini untuk memperbaiki proses pembelajaran dalam pelajaran fisika sehingga dapat meningkatkan penguasaan konsep siswa. Deskripsi data penguasaan konsep siswa yang dipaparkan meliputi nilai mean (rata- rata). Nilai rerata penguasaan konsep fisika siswa yang menggunakan model PBL berbasis asesmen kinerja yaitu, $\bar{X}=87,15$, sedangkan nilai penguasaan konsep fisika siswa yang menggunakan model PBL yaitu, $\bar{X}=$ 78,18. Uji prasyarat dilakukan sebelum menggunakan uji hipotesis 


\section{C, R, Jehanus., H, D, Ayu., C, Sundaygara. - Pengaruh Problem Based ...}

yaitu uji uji anova dua jalur. Uji normal dan homogen maka prasyarat tersebut meliputi uji selanjutnya dilakukan uji hipotesis normalitas dan uji homogenitas menggunakan uji anova dua jalur. varians. Setelah data yang diuji

Tabel 2. Hasil Uji Anova Dua Jalur

\begin{tabular}{ll}
\hline \multicolumn{1}{c}{ Source } & Sig. \\
\hline Model_Pembelajaran & .000 \\
Kerja_Ilmiah & .019 \\
Model_Pembelajaran * & .007 \\
Kerja_Ilmiah & \\
\hline
\end{tabular}

Berdasarkan tabel 2 dapat diketahui bahwa terdapat perbedaan penguasaan konsep fisika yang lebih baik untuk siswa yang belajar menggunakan model PBL berbasis asesmen kinerja dibandingkan dengan siswa yang belajar menggunakan model PBL . Hal tersebut terbukti dari nilai sig $<\alpha \quad(0,000<0,05)$. Hal ini disebabkan karena dalam pembelajaran model PBL berbasis asesmen kinerja sebelum melaksanakan kegiatan pembelajaran guru menjelaskan kepada siswa indikator pembelajaran yang harus dicapai siswa pada setiap fase pembelajaran karena guru akan melaksanakan penilaian terhadap kinerja siswa dalam memecahkan permasalahan yang diberikan oleh guru tersebut (Dewi et al., 2016). Oleh karena itu, siswa dituntut untuk terlibat secara aktif dalam memecahkan masalah agar mampu mencapai semua indikator pembelajaran yang terdapat pada setiap fase pembelajaran dengan kemampuan berpikir lebih tinggi. Aktivitas belajar dengan adanya penggunaan model ini dapat mempermudah siswa dalam menguasai materi dan siswa tidak cepat merasa bosan dalam mengikuti proses pembelajaran (Arinata et al., 2017). Selain itu mendorong siswa untuk mampu menyelesaikan berbagai masalah dari berbagai sudut pandang dan memunculkan berbagai gagasan untuk menyelesaikan permasalahan yang muncul. 
Kemampuan kerja ilmiah juga mampu membantu siswa untuk meningkatkan penguasaan konsepnya, karena siswa dengan kemampuan kerja ilmiah lebih tinggi cenderung lebih mandiri dalam proses belajar karena mereka dilatih untuk menyelidiki sendiri permasalahan yang diberikan oleh guru. Selain itu siswa dengan kemampuan kerja ilmiah tinggi memiliki kemampuan yang cenderung cepat dan tanggap dalam menyelesaikan permasalahan. Siswa yang mempunyai kemampuan kerja ilmiah cenderung mandiri dalam proses pembelajaran (Martuti, 2013:97). Dalam melaksanakan kegiatan penyelidikan atau praktikum, siswa yang mempunyai kemampuan kerja ilmiah tinggi lebih mudah dalam memecahkan permasalahan yang diberikan oleh guru dan mampu melaksanakan kegiatan praktikum secara sistematis. Siswa yang mempunyai kemampuan kerja ilmiah kegiatan belajar dan unjuk kerjanya lebih terarah dan pengembangan konsepnya lebih luas. Dengan demikian, penguasaan konsep fisika siswa dengan kemampuan kerja ilmiah tinggi cenderung lebih tinggi daripada siswa dengan kemampuan kerja ilmiah rendah.

\section{PENUTUP}

\section{Kesimpulan}

Berdasarkan Aplikasi asesmen kinerja pada model PBL memberikan maanfaat yang besar dalam pembelajaran fisika. Kelebihannya adalah proses pembelajaran lebih efektif, efisien dan lebih mengaktifkan siswa selama proses pembelajaran. Selain itu kegiatan kerja ilmiah juga mendorong siswa lebih mengutakan kinerja dalam menguasai dan memecahkan masalah yang diberikan guru. Hasil penitian pun menunjukkan bahwa model PBL berbasis asesmen kinerja berpengaruh terhadap penguasaan konsep fisika yang ditinjau dari kemampuan kerja ilmiah siswa.

\section{Saran}

Berdasarkan hasil penelitian yang telah diperoleh selama melakukan proses pembelajaran, maka Penulis mengharapkan mengingat model PBL berbasis asesmen kinerja cukup efektif guru diharapkan dapat menerapkannypada kegiatan pembelajaran;mengingat penerapan 
asesmen kinerja dalam pembelajaran membutuhkan waktu yang cukup banyak, maka guru perlu mengefisien penggunaan waktu pembelajaran; Untuk memperlancar model PBL berbasis asesmen kinerja, maka siswa dituntut untuk lebih meningkatkan unjuk kerja dalam memecahkan masalah yang diberikan guru.

\section{DAFTAR PUSTAKA}

Arinata, D.C.A., Suniasih, W.N.,\& Darsana, W. I. 2017. : e-Journal PGSD Universitas Pendidikan Ganesha Mimbar PGSD : Pengaruh Model Problem Based Learning Berbasis Penilaian Kinerja Terhadap Kompetensi Pengetahuan IPA Siswa Kelas IV, 5 (2), 1-9

Ayu, H. D \& Jufriadi, A. 2017. Pengaruh Penerapan Strategi Open Ended Problem Bersetting Kooperatif Terhadap Kemampuan Menyelesaikan Masalah Ditinjau Dari Kreativitas Siswa SMP PGRI 6 Malang. Jurnal Ilmu Pendidikan, 7 (1), 1-6

Ayu, H. D., Pratiwi, H. Y., Sentot, K., \& $\quad$ Muhardjito. 2017. Pengembangan E-Scaffolding Untuk Meningkatkan Kualitas Proses Dan Hasil Belajar. Jurnal Kependidikan, 1 (2), 334 - 347

Ayu, H. D., Sundaygara, C., \& Pratiwi, H. Y. 2015. Pengembangan Model Perkuliahan Berbasis On-Line Untuk Menunjang Pembelajaran Matakuliah Telaah Kurikulum Pendidikan Fisika. Prosiding
Seminar Nasional Penelitian LPPM Universitas Kanjuruhan Malang, 46-52. Retrieved from http://repository.unikama.ac.id/833 /1/Artikel\%20hesty\%20prosiding \%202015.pdf

Dewi, T. M. A., Suwatra, W.I., \& Sumantri, M. 2016. Penerapan Model Problem Based Learning Berbantuan Asesmen Kinerja Untuk Meningkatkan Hasil Belajar IPA. Jurnal PGSD Universitas Pendidikan Ganesha, $1(4), 1-10$

Hudha, M. N \& Aji, S. D. 2016: Kerja Ilmiah Siswa SMP dan SMA Melalui Authentic Problem Based Learning (APBL). Jurnal Inspiraasi Pendidikan, 6 (1), 835841

Martuti, R. 2013. Pengaruh Pembelajaran Open Inquiry terhadap Prestasi Belajar Fisika Ditinjau dari Kerja Ilmiah Siswa SMA Negeri 1 Blitar. Jurnal Pendidikan Sains, 1 (1) : 92-99

Pelawi, S.H \& Sinulingga, K. 2016. Pengaruh Model Problem Based Learning Dan Motivasi Belajar Terhadap Hasil Belajar Siswa Di Kelas X SMA Swasta Sinar Husni. Jurnal Pendidikan Fisika, 5(1), 3237.

Sinensis, A. R., \& Firdaus, T. 2017. Keterampilan Dasar Kinerja Ilmiah Pada Mahasiswa Calon Guru Fisika. Jurnal Pendidikan Fisika, 5(2), 102-110

Yoesoef, A. 2015. Penerapan Model Problem Based Learning Untuk Meningkatkan Kemampuan Menanya Dan Penguasaan Konsep Fisika Kelas $X$ MIA 1 SMA Negeri 2 Kediri. Jurnal Pinus, 1 (2), 96-102 